\title{
THE IMPACT OF ZAKAT ON MONEY DEMAND FUNCTION: EVIDENCE FROM MUZAKKI IN INDONESIA
}

\author{
Atika Rukminastiti Masrifah ${ }^{a}$ \\ Fajrin Intan Safitri ${ }^{\text {b }}$ \\ ${ }^{\mathrm{a}, \mathrm{b}}$ Islamic Economics Department, Faculty of Economics and Management, University of \\ Darussalam Gontor \\ Email: atikamasrifah@unida.gontor.ac.id ${ }^{a}$; fajrinintan25@gmail.com ${ }^{\text {b }}$
}

\begin{abstract}
ARTICLE HISTORY
Received:

28 July 2021

Revised

07 November 2021

Accepted:

15 November 2021

Online available:

30 November 2021

Keywords :

Islamic Money Demand, Social Value,

Zakat,

Muzakki,

Structural Equation,

Modelling.

*Corespondence:

Name: Atika

Rukminastiti Masrifah

Email:

atikamasrifah@unida.go

ntor.ac.id

ABSTRACT

Most research in the Islamic economy on the money demand have employed the Keynesian approach, while in this research money demand functions are derived from a microeconomic approach. Thus, the aim of this study is to test and analyze some of the key factors in Islamic money demand model with the microeconomicsbased approach, and then, in accordance with Islamic principles, chooses muzakki as the best sample. The data source for this study is 200 muzakki in Java, with a period of 2020. Structural Equation Modelling (SEM) is adopted to examine the relationship between the seven constructs, i.e., zakat, PLS rate, state, regulation, goods and services, conspicuous consumption, and money demand. The systemic relationship between the structures indicates that the integrated model of demand for money has a strong zakat relationship, while reliability and validity have been established. Zakat plays a key role in applying the established paradigm of demand for money in relation to goods and services. Zakat significantly affects both goods and services as well as models of money demand. This proposed new model equation is intended to help each household economic actor increase the demand for philanthropic money. As many muzakki are spread throughout Indonesia, it is expected that the welfare of the poor and the lowincome society will gradually improve and, finally, the distribution of income in Indonesia will be on an equal footing.
\end{abstract}

\section{INTRODUCTION}

The role of demand for money, which now prevails after several stages of evolution, has entered into existence. The topic of money demand is central and crucial to monetary theories that have captured the attention of many economists. The idea of the need for money has led to many developments over time with rich literature. 
There was quite a lot of dynamic and insightful discussions about the demand for money. Several factors are taken into consideration, including interest rates, total income, total output, nominal revenue, permanent income, capital and salaries, inflationary expectations, institutional adjustments and financial developments. The Keynesian methodology was used for most studies in the conventional economy on demand for money (Calza \& Zaghini, 2010; Dreger \& Wolters, 2010; Mazher \& Dahlan, 2020; Padhan, 2011; Riyandi, 2012; Suliman \& Dafaalla, 2011).

On the other hand, Islam finds that interest is not an adequate or fair tool for controlling money demand. Therefore, it attempts a strategy that relies on moral values to regulate money demand. Besides reducing the use of interest rates, money demand also lowers unproductive and speculative targets in Islamic view (Chapra, 1996; Gustiani et al., 2010). Demand for money in an Islamic economy could appear to be more stable sincespending focused on needs and efficient investments tends to be more sustainable than conspicuous consumption and speculative investments..

In the Islamic economic system, there have always been different models of money demand. (Chapra, 1996) explained that Muslim economists have frequently investigated money demand in Islamic economics using Keynesian theory, i.e., they divided money demand in terms of its motives and the function of money in the economy in general. Furthermore, Mir Moezi (2003) claimed that in Islamic economics, holding money for the purpose of speculating is permissible under Islamic law. Finally, Esmaeili et al. (2012) discussed the possibility of financial asset speculation. The asset market would be less speculative if central banks implemented Islamic contract norms. However, there were some limitations in the presentation of money demand for the Islamic economy in contrast to conventional money demand literature. The models that have been made concerning this matter have not mentioned how to choose the specific model for money demand function in Islamic microeconomics.

Today, the derivation of money demand models using micro approach is of greater interest in macroeconomics. The interesting point of this research on money demand with micro approach is the researchers sought to prove the findings of Gustiani, et al. (2010), who claimed that social values (zakat) have a negative impact on the demand for money in the Islamic system on the side of muzakki and a positive impact on the side of mustahik. Consequently, providing a model for the money demand in the Islamic economy based on microeconomics and reviewing the behaviour of muzakki in accordance with the Islamic requirements are necessary.

This said, in this study, the authors plan to update the proposed money-demand models for the Islamic economy, pay attention to micro aspects of the models and, finally demonstrate muzakki's behaviour in respect of their money-demand-based model questionnaires. The second section of this paper will discuss the theory and points of 
view of existing literature, and the third section will discuss methodology. The fourth section discusses the estimation results, and a conclusion is provided at the end of the paper.

\section{LITERATURE REVIEW}

The nature of money raises a number of opinions from a wide range of economists on the theory of money, particularly the need for money. From the contemporary point of view, there is a certain economic flow. It's the classic economic flow, Keynes. Classic in Money Demand has two perspectives: demand for money from Irving Fisher and Cambridge Theory. Some economists assume that the theory varies from one another, but that it still has a simple equation and is generally referred to as the "Quantity Theory of Money" (Crouch, 2002).

The two viewpoints of Classic's need for money are first, Fisher shows that the demand for money would result from the use of some money in the purchase process. Finally, the study is limited to the amount of national income and is not influenced by other considerations, such as the interest rate (Boediono, 2016).

Second, Cambridge's theory of money demand. Theory of Cambridge, not that different from that of Fisher and the other classical theory, since it has the same concept as the role of money as a general medium of trade. In fact, however, there is also a difference between Irving Fisher and the Cambridge theory. The most notable distinction is that according to Marshall, monetary research focused on the notion of need for capital has made it more realistic than an alternate approach to transaction speed (Whitaker, 1990).

Keynes is also the contemporary theory of money demand, while Keynes's theory is elaborated by a number of economists who developed theory focused on money demand, along with Baumol-Tobin's theory of money sales demand in Keynes's growth, and Tobin's theory of cash demand speculation in Keynes' development (Boediono, 2016).

Yet money demand theory was distinct from standard monetary demand theory, from an Islamic viewpoint. Umer Chapra built a paradigm of money demand in Islam's economic thought. There are two components of demand: firstly, demand-filling consumption; and, secondly, the visible and unsustainable consumption, unproductive investment. (Chapra, 2000).

The tool of social values, which is based on demand, derives from Umer Chapra's principle of demand for capital. The Chapra variant on money in the Islamic economy can thus be expressed by the following equation using Keynes' basic theorem (Karim, 2015): $\mathrm{Md}=\mathrm{f}(\mathrm{Ys}, \mathrm{S}, \pi)$ 
Where Ys represents goods and services related to demands and efficient savings, in accordance with Islamic values. S represents all of the moral and social values, including zakat, that affect the distribution and allocation of resources, which can reduce to a minimum the MDs for conspicuous consumption and nonproductive investment as well as precautionary and speculative steps. $\pi$ is the benefit or loss rate within the scheme that does not permit the use of interest by financial intermediation.

This realization can lead economists to recognize core principles and structures that influence the allocation of resources to improve measurement techniques, and at least to include them. It may also contribute to finding non-coercive ways to upgrade these principles and allow them to minimize the inessential and inappropriate component of Md more effectively. The economist will then not only analyze what happens, but what needs to be achieved to realize Maqasid Sharia.

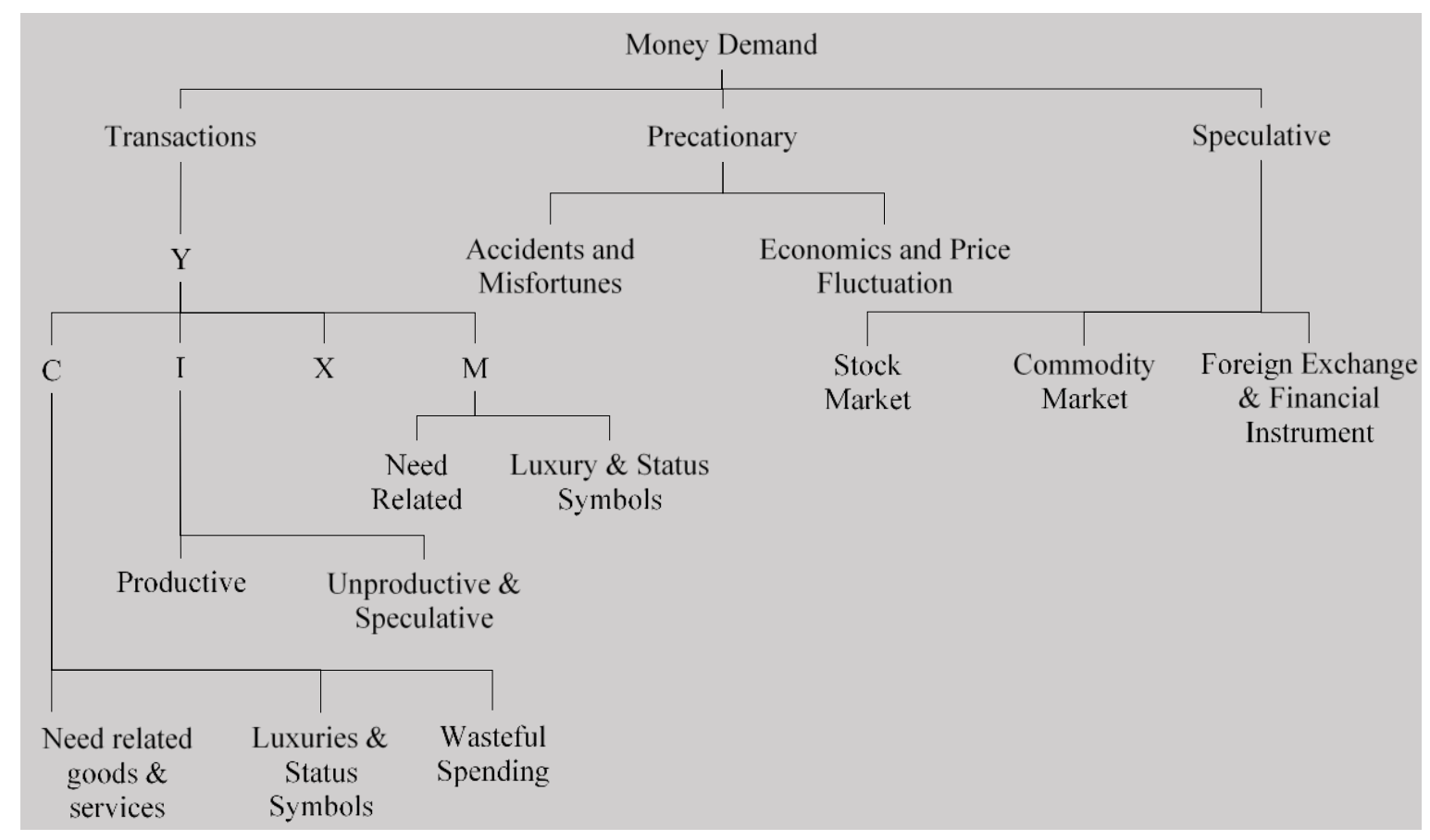

Source: Chapra, 1996

Figure 1. Chapra's Concept of Money Demand 
The definition of money demand can therefore mathematically be inferred in conventional and Islamic equation:

Table 1

Money Demand Concept

\begin{tabular}{cccc}
\hline No. & The Theory of Money Demand & $\begin{array}{c}\text { The Concept of Money } \\
\text { Demand }\end{array}$ \\
\hline 1. & Islam & Chapra & $M_{d}=f\left(Y_{s}, S, \pi\right)$ \\
\hline 2. & Irving Fisher & $M_{d}=\frac{1}{V \cdot T} P . T$ \\
3. & Marshall-Pigou & $M_{d}=k . Y$ \\
4. & Keynes & $M_{d}=L(Y . r)$ \\
5. & Baumol & $\frac{M_{d}}{p}=\sqrt{\frac{Y F}{2 i}}=L(i, Y, F)$ \\
\hline
\end{tabular}

\section{Social Values on Islamic Money Demand}

The theory of money demand in traditional businesses defied Islamic demand for money. Humans are social beings that are not able to survive by themselves or rely on other people. The interaction form for constructing a structure is a social system, it can connect two "actors" and more on a socio-cultural level. The actor is either an individual person) focused or a part of plurality. The social contact mechanism is where the social group's 'conduct' influences the role of the system and the state of the relationship (Smelser, 2005).

One of Islam's most important aims is to make human culture more equal. One universal requirement is that any aspect of human life should be committed to universal values, social, physical, political and foreign. It would help to limit envy and greed, which are the main markers of human success, increase richness and satisfaction (Muhammad Umer Chapra, 2011).

Chapra (1979) argued that Islam is attempting to minimize the keeping of idle funds by zakat in order to decrease the need for capital for unproductive investments and speculative purposes. This situation continues to encourage savers to participate in profitable transactions and spend to prevent zakat eroding their net worth.

As consumption and profitable investments dependent on demand tend to be more stable than apparent consumption and risky investments, demand for capital will tend to be more stable in the Muslim economy. The numerous elements of Islamic economics can also affect different elements of monetary demand in such a manner that increases money productivity and equity can be encouraged to reduce the volatility of aggregate demand. More stable demand will also contribute to more stable monetary circulation in Muslim economies (Chapra, 1996). 


\section{Previous Study}

The element that affects the money demand in Indonesia has been studied by Setiadi (2012). Research indicates that inflation has a favorable and important effect on money demand in Indonesia in the short and long run, and that interest rates have a negative and negligible relationship in the short term while in the long run, have a negative impact on money demand in Indonesia and have a positive impact on the domestic gross production in the near term (GDP).

Widodo (2015) has shown that long term money demand (M1) in Indonesia was affected positively and significantly by the variables Gross Domestic Product (GDP) and price levels on macroeconomic factors that affect the demand for money in Indonesia. In consideration of the volatile currencies of interest, the market for capital has a negative impact. Chapra (1996) on the management of monetary matters in an Islamic economy concluded that reducing the conspicuous consumption (excessive consumption, speculation), in accordance with the moral principles of any application like ziswaf, would establish productivity and economic balance.The influences of social principles against the amount of money has in Indonesia (Gustiani et al., 2010). The usage of VAR and VECM shows that if society is more stable, then assuming that money demand is increasing, GDP (Gross Domestic Product) has a major impact on the monetary demand (with the exception of wadi'ah) both in Islamic as in conventional systems.

Money demand activity in Indonesia is studied by Ascarya et al. (2008). Using VAR and the VECM, income return (mudharabah) showed a negative influence on Islamic money demand (fiat money, current account, investments and deposits of mudharabah). With traditional demand for money, rates of interest have a significant effect on monetary demand (20 to $29 \%$ ), while the Islamic money demand has no impact on the conduct of Islamic money demand in mudharabah. It can be seen to respond to shocks from other factors that Islamic money needs more stable than conventional money demands.

In addition, Sadeghi and Rofougar (2019) investigated the relationship between money demand and income and sukuk rental rates. The marginal product of capital as a result of an additional unit of income spent for Infaq (spending in Allah's way) is determined by the expected inflation rate, depreciation rate, and Sukuk rental rates. According to the findings, M1 and M2 money demand are co-integrated with sukuk income and rental rate. In addition, in a study by Kia and Darrat (2007), by using data from Iran, the study proved the stability of money demand models in the interest-free economy. Finally, the money demand function for the Islamic economic system was derived from an economic environment free of interest. Their studies reviewed the demand for money in a non-Riba economy. 
There are several reports that concentrate both on money demand and Islamic money demand. There are however, no studies that concentrate on micro-presumption demand for Islamic money. This analysis would examine the determinant of the demand for islamic money by using muzakki data. Muzakki's ability is great, because in Islam, muzakki charged zakat as the social values. Zakat may also be viewed as an Islamic money demand feature. Moreover, social value, rate of PLS, state and regulation were exogenous, while the endogenous variables were products and services, conspicuous consumption and the market for Islamic money. Finally, in order to investigate the relationship among the exogenous and endogenous variables in the models, Structural Equation Model (SEM) approach developed by Jöreskog and Sörbom (1982) has been employed.

\section{Research Framework}

The researchers construct the following conceptual and empirical structure on the basis of the above-mentioned literature reviews. The three latent endogenous variables, namely goods and services, conspicuous consumption, and Islamic money demand, are shown as described in Figure 1. Researchers also include social values, PLS rate, state, regulation, latent exogenous variables.

The alternative goals on proxies for the Islamic money demand are to increase Islamic motive of holding money, Islamic motive of holding money for business capital, Islamic motive for increasing business income and profit. In this context, researchers are developing, evaluating and validating our empirical model. The results of the estimation and the assessment will be used to draw conclusions. The outcome is expected to lead to a number of policy suggestions on how to generate Islamic money demand in the integration model.

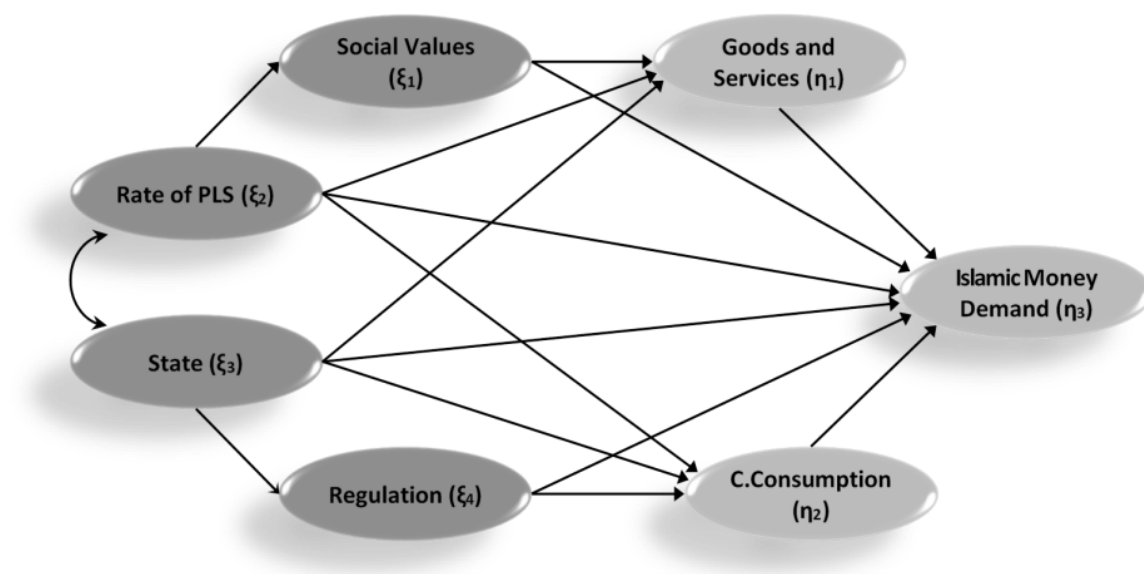

Figure 2. Conceptual Framework of Islamic Money Demand Evidence from Muzakki in Indonesia

Published by University of Airlangga.

This is an open access article under the CC BY license (https://creativecommons.org/licenses/by-nc-sa/4.0/) 


\section{RESEARCH METHODS}

A quantitative approach to hypotheses testing is adopted by a survey conducted by the zakat Institution in Java. The survey respondents in this study are assatidz or teacher, musyrif or male mentor, and musyrifah or fermale mentor, who have income and give part of their income to pay zakat. On average, a sample size of between 200 and 400 is considered sufficient for good results (Hair et al., 2006). It is also suggested that a minimum of 200 is also useful for each statistical analysis (Hoe, 2008).

Some people tend to put the sample by the amount of parameter or items in the analysis. In others studies using the Structural Equation Model (SEM), a sample size of at least 100 is required (Wijanto, 2015). Bagozzi and Yi (2012) also shared his view that SEM sample sizes should exceed 100 participants. The original sampling size was specified by 200 organizational representatives, assatidz or teachers, musyrif, musyrifah, or persons who have income and share of their income to pay zakat. These opinions are based on this study (Bagozzi \& Yi, 2012; Wijanto, 2015).

The new model that integrates the social values motive and money demand function to increase Islamic motive for holding money effectively was suggested in this section. The suggested integrated social value motive and money demand model, composed of seven important parts, led in twelve hypotheses to be tested. The prospective connections between the variables are the basis for these hypotheses.

SEM model of this study comprises of latent exogenous variables, namely Social Values $\left(\xi_{1}\right)$, PLS Rate $\left(\xi_{2}\right)$, State $\left(\xi_{3}\right)$ and Regulation $\left(\xi_{4}\right)$ as well as four latent endogenous variables, namely goods and services $\left(\eta_{1}\right)$, conspicuous consumption $\left(\eta_{2}\right)$, and Islamic money demand $\left(\eta_{3}\right)$. Table below shows the latent variable's comprehensive indicators. The comprehensive empiric SEM model of this study is shown in table below, which provides social values that can integrate Islamic money demand into the micro-economic model.

Table 2

Definition of Variables

\begin{tabular}{|c|c|c|c|c|}
\hline No. & Variables & Definition & Proxy & Reason \\
\hline 1. & $\begin{array}{l}\text { Goods and } \\
\text { Services }\end{array}$ & $\begin{array}{l}\text { The amount of money that } \\
\text { allocated to meet the } \\
\text { necessities of good and service } \\
\text { to muzakki within a month. }\end{array}$ & $\begin{array}{l}\text { Needs } \\
\text { Goods and } \\
\text { Service }\end{array}$ & $\begin{array}{l}\text { The main needs of goods } \\
\text { and service for life. }\end{array}$ \\
\hline 2. & $\begin{array}{l}\text { Conspicuous } \\
\text { Consumption }\end{array}$ & $\begin{array}{l}\text { The amount of money for } \\
\text { transaction to get the } \\
\text { conspicuous consumption }\end{array}$ & $\begin{array}{l}\text { Price } \\
\text { Brand }\end{array}$ & $\begin{array}{l}\text { To measure Conspicuous } \\
\text { consumption of } \\
\text { respondents. }\end{array}$ \\
\hline 3. & Money Demand & $\begin{array}{l}\text { The amount of muzakki money } \\
\text { measured by the average cash } \\
\text { money they hold in a month. }\end{array}$ & $\begin{array}{l}\text { Money } \\
\text { Demand }\end{array}$ & $\begin{array}{l}\text { Money demand is money } \\
\text { held by society or company. }\end{array}$ \\
\hline
\end{tabular}




\begin{tabular}{|c|c|c|c|c|}
\hline 4. & Social Values & $\begin{array}{l}\text { The amount of money } \\
\text { allocated for charity to } \\
\text { muzakki and for economic } \\
\text { activities within a month. }\end{array}$ & $\begin{array}{l}\text { Charity } \\
\text { Economic } \\
\text { Activity }\end{array}$ & $\begin{array}{l}\text { Social economic activity } \\
\text { that influences the } \\
\text { allocation of money that } \\
\text { can help minimize Md, not } \\
\text { for conspicuous of } \\
\text { respondents. }\end{array}$ \\
\hline 5. & $\begin{array}{l}\text { The Rate of } \\
\text { Profit or Loss in } \\
\text { a System }\end{array}$ & $\begin{array}{l}\text { The amount of money } \\
\text { allocated for rate of profit or } \\
\text { loss in some system, which is } \\
\text { for needs within a month. }\end{array}$ & $\begin{array}{l}\text { Interest } \\
\text { Profit }\end{array}$ & $\begin{array}{l}\text { Allocated for rate of profit } \\
\text { or loss in some system. }\end{array}$ \\
\hline 6. & $\begin{array}{l}\text { Total Financial } \\
\text { State }\end{array}$ & $\begin{array}{l}\text { The amount of money } \\
\text { allocated to pay the obligation } \\
\text { from the government. That is } \\
\text { allocated for improving the } \\
\text { public goods of the state. }\end{array}$ & $\begin{array}{l}\text { Public goods } \\
\text { Business } \\
\text { Cycle } \\
\text { Interest rate } \\
\text { State Budget }\end{array}$ & $\begin{array}{l}\text { Allocation money for pay } \\
\text { the obligation from the } \\
\text { government. }\end{array}$ \\
\hline 7. & Regulation & $\begin{array}{l}\text { The amount of money } \\
\text { allocated to pay the regulation } \\
\text { form the government of the } \\
\text { country. Such us E-Money, } \\
\text { regional minimum wage, etc. }\end{array}$ & $\begin{array}{l}\text { E-Money } \\
\text { Regional } \\
\text { Minimum } \\
\text { Wage }\end{array}$ & $\begin{array}{l}\text { Allocation money for pay } \\
\text { the regulation from the } \\
\text { government. }\end{array}$ \\
\hline
\end{tabular}

Source: Chapra (1996); Chapra (2001); Gustiani et al. (2010); Sude and Umam (2018)

\section{Structural Equation Model}

In combination with the Keesling (1973) and Wiley (1973) model, also Jöreskog and Sörbom (1982) developed the structural equation model (Winarsih et al., 2019). It is known as the 'Structural Linear Relation' or LISREL. The most important reason of the spread of this statistical technique is that the direct and also indirect relationships between among causal variables can be measured with some single model (Civelek, 2018). The research was also performed using the SEM program, Lisrel 8.70 , to provide a fitness indice and to determine how well the data match the recommended model.

SEM is frequently used in various behavioral studies. The CFA and Structural Model are integrated in a systematic statistical framework in an integrated statistical test (Winarsih et al., 2019). It is a valuable way in which inferential knowledge is evaluated and checked. One advantage of SEM is that many variables and their connections are simultaneously calculated. It also makes multiple dependent ties between variables (Wijanto, 2015).

Prior to SEM, the latent structures were examined, so that the results were tested and the structures in the suggested model were estimated. As a result, seven structures or components of an integrated Islamic value were entered into the SEM as unobserved variables in terms of the holding money model: 1) social values; 2) PLS rate; 3) economy; 4) goods and services; 5) consumption; and 6) Islamic money demand.

Published by University of Airlangga.

This is an open access article under the CC BY license (https://creativecommons.org/licenses/by-nc-sa/4.0/) 
This allowed researchers to apply this multivariate technique to validate the relationship between unobserved variables (Hair et al., 2006). Islamic money demand, for example, is one part or the other of the variables derived from the factors observed, such as the expansion of the Islamic motive for holding money, the Islamic motive for commercial capital, the Islamic motive for increasing business income and profit, and others.

\section{Measurement and Structural Model}

A combination of factor analysis and path analysis was the two main components of the SEM model, that is, the measuring model and the structural pattern. The measurement model is a model that explores the relation of the latent and its indicators. The model refers to the relationship of latent variables. The measuring model shows that a latent variable has a relationship with its indicators. The causal relationship may include several calculated indicators in the estimation of the latent variable value.

Structural Equation Modelling (SEM) has two types of latent variables, namely exogenous on all equations in the model. Notation of exogenous latent variables is $\xi$ (ksi) and endogenous latent variables are marked with $\eta$ (eta) (Ascarya and Masrifah, 2016). The structural model is a relationship that exists between latent variables. This relationship is generally linear, although it is possible that SEM has a non-linear relationship. The relationship between latent variables is similar to a linear regression equation between latent variables.

Parameters that shows regression of endogenous latent variables on exogenous variables are labeled as $\gamma$ (gamma), while for regression endogenous latent variable in endogenous latent variables are labeled as $\beta$ (beta). The latent exogenous (Xn) indicators, with causal dependence labeled as $\lambda \mathrm{Xn}$ "lambda $\mathrm{Xn}$ " and $\delta \mathrm{n}$ 'delta' is referred to measurement error for latent exogenous. Meanwhile, the latent endogenous ( $\mathrm{Yn}$ ) indicator, with causal dependence labeled as $\lambda \mathrm{Yn}$ "lambda Yn " and En 'epsilon' is referred to measurement error for latent endogenous. 


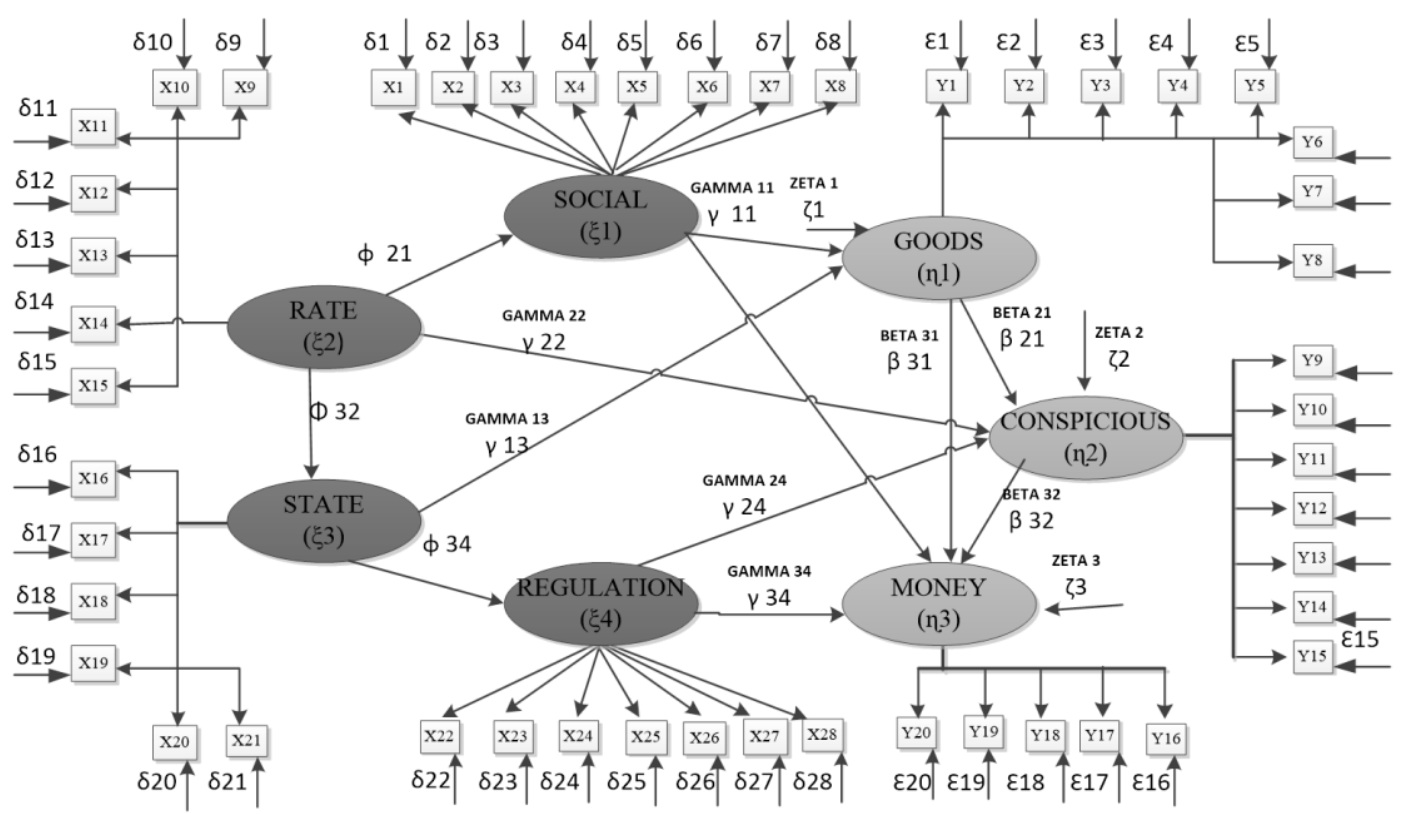

Figure 3. Measurement Model of SEM

The above figure shows the measurement model examples. In the following equations, these measurement models can also be reinterpreted Latent exogenous $\xi_{1}$ :

$\mathrm{x}_{1}=\lambda \mathrm{x}_{1} \xi_{1}+\delta_{1} \ldots \mathrm{x}_{8}=\lambda \mathrm{x}_{8} \xi_{1}+\delta_{8}$

Latent exogenous $\xi_{2}$ :

$X_{9}=\lambda x_{9} \xi_{9}+\delta_{9} \ldots X_{15}=\lambda x_{15} \xi_{2}+\delta_{15}$

Latent exogenous $\xi_{3}$ :

$x_{16}=\lambda x_{16} \xi_{16}+\delta_{16} \ldots x_{21}=\lambda x_{21} \xi_{3}+\delta_{21}$

Latent exogenous $\xi_{4}$ :

$x_{22}=\lambda x_{22} \xi_{22}+\delta_{22} \ldots x_{28}=\lambda x_{28} \xi_{4}+\delta_{28}$

Latent endogenous $\eta 1$ :

$\mathrm{Y}_{1}=\lambda \mathrm{y}_{1} \eta_{1}+\varepsilon_{1} \ldots \mathrm{Y}_{8}=\lambda \mathrm{y}_{8} \eta_{1}+\varepsilon_{8}$

Latent endogenous $\eta 2$ :

$Y_{9}=\lambda y_{9} \eta_{2}+\varepsilon_{9} \ldots Y_{15}=\lambda y_{15} \eta_{2}+\varepsilon_{15} \ldots$

Latent endogenous $\eta 3$ :

$Y_{16}=\lambda y_{16} \eta_{3}+\varepsilon_{16} \ldots Y_{20}=\lambda y_{20} \eta_{3}+\varepsilon_{20}$

The structural model refers in the meantime to the direct relationship between latent variables. However, the endogenous variables can be mediating or strictly dependent, but they are not initially causal. 


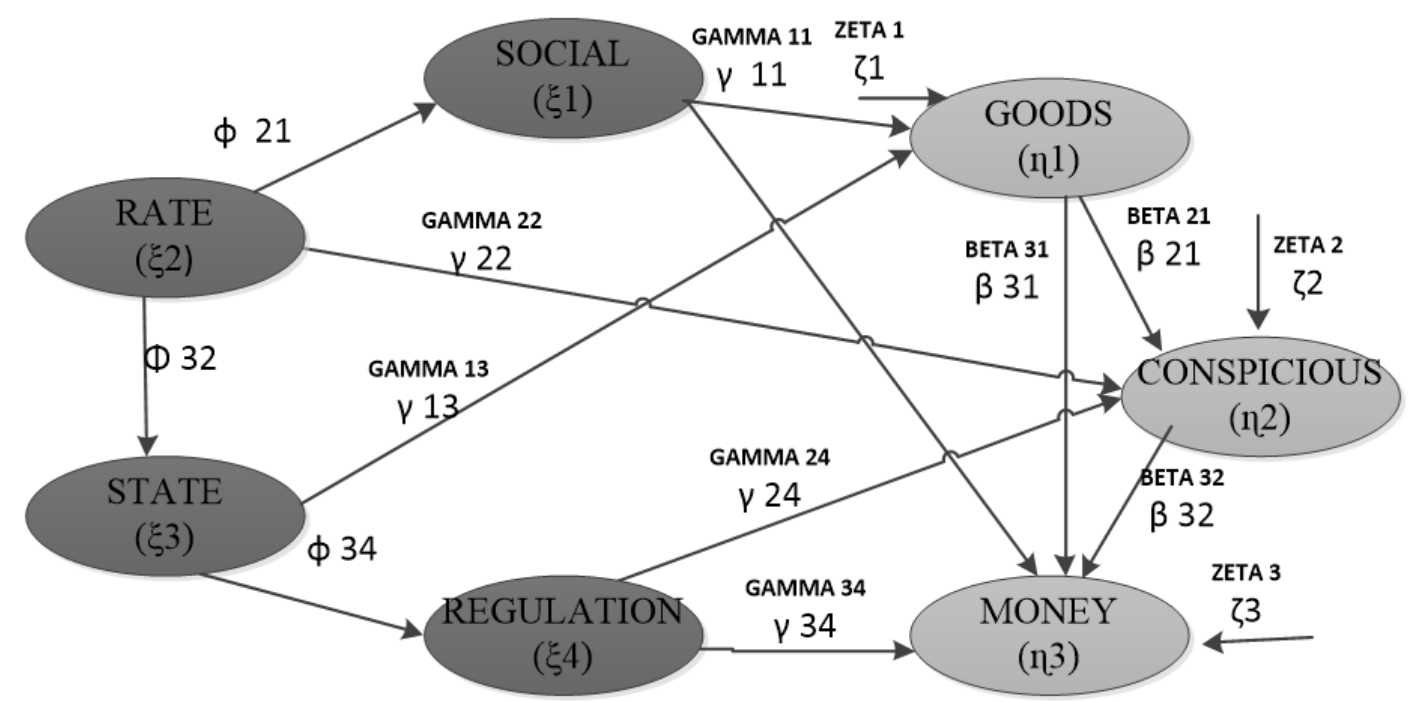

Figure 4. Structural Model of SEM

The above figure shows the structural model examples. In the following equations, these structural models can also be reinterpreted.

$\eta_{1}=\nu_{11} \xi_{1}+\nu_{13} \xi_{3}+\zeta_{1}$

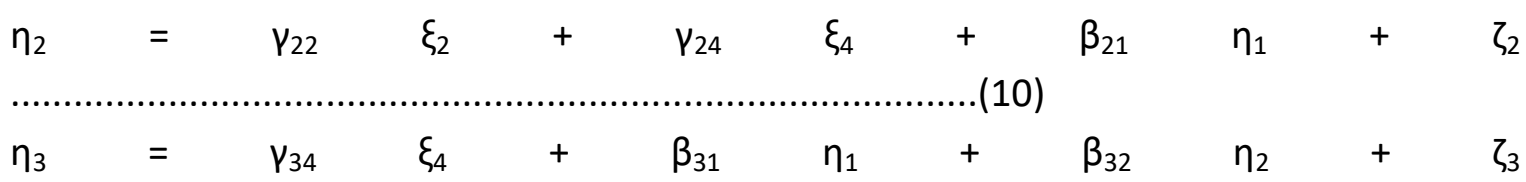

SEM was estimate the hypothesized model. First, a confirmatory factor analysis (CFA) was conducted to determine whether the observed measures loaded on the latent constructs as hypothesized. The first model estimated only a direct path from social values to money demand. The second model retained the direct path from the baseline model and added the indirect influence of social values on money demand (Cleveland et al., 2005).

SEM consists of five phases which are specification, identification, estimation, goodness of fit test, and respecification (Winarsih et al., 2019). The model specification consists of the translation in a series of equations previously seen as a path diagram of the verbal hypotheses. Figure 5 shows a route chart suggested in the quest for integration of the social value and money demand function. 


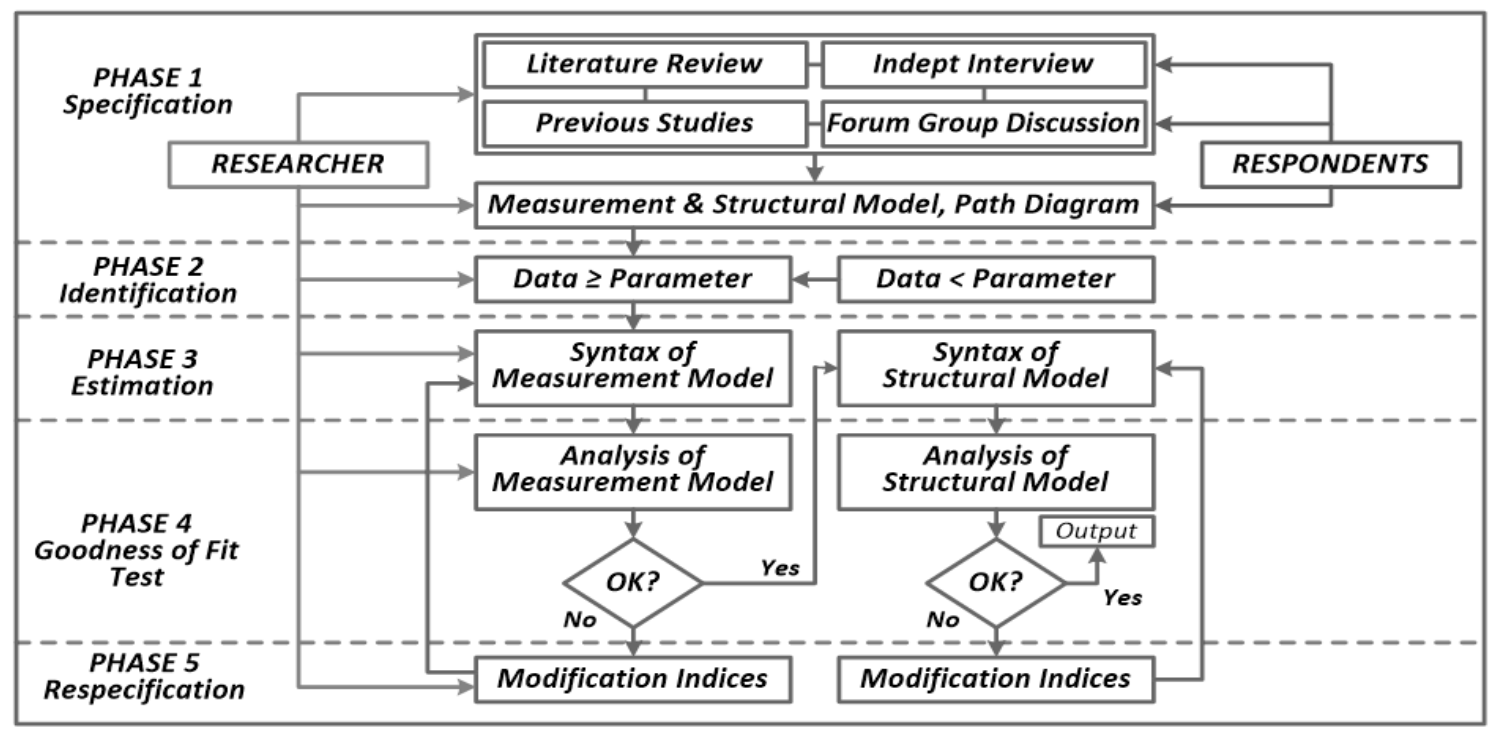

Source: Winarsih, et al. (2019)

Figure 5. Stage of Research

In this second step all observed variables indicated in the model are collected to extract the model parameter from an observable collection of variance and covariance. The third step estimates the value of the parameter, like the standardized path coefficients. There is a wide array of literature, resulting in a collection of measurement technologies, such as Maximum Likelihood (ML), Generally Weighted Least Square (WLS), Unweighted Leas Square (ULS), Generalized Least Square (GLS). The most commonly used is ML (Browne, 1984).

The next phase is the statistical process to evaluate whether this model is compatible with the information. This is achieved through a goodness of fit test. Because of their complexity, models are generally dismissed by the goodness of fit test, so that the model requires to be changed to enhance its fit or simplicity at this last phase. The SEM stage summary is illustrated in the above figure.

The routes of regression are indicated in SEM by unidirectional arrows. In the Islamic money demand, for example, the unidirectional arrow in the integrated Islamic social values in the money demand points to the endogenous factor, Islamic money demand, assumes that exogenous factor namely social values, PLS rate, state, regulation cause Islamic money demand (see Figure 3). Islamic money demand is identified in the integrated Islamic social values in the money demand model as the dependent variable. 


\section{RESULT AND ANALYSIS}

The results of seven measurement models will be discussed, consisting of four latent exogenous variables and three latent endogenous variables.

Table 3

Fit Indices for Measurement Models

\begin{tabular}{lccccccc}
\hline \multirow{2}{*}{ Fit Index } & \multicolumn{4}{c}{ Latent Exogenous } & \multicolumn{3}{c}{ Latent Endogenous } \\
\cline { 2 - 8 } & SV & PLS & ST & RG & GS & CONS & ISMD \\
\hline $\mathbf{X}^{2}$ & 41.11 & 9.36 & 6.49 & 21.96 & 28.14 & 24.34 & 14.40 \\
$\mathbf{d f}$ & 9 & 9 & 8 & 10 & 13 & 11 & 8 \\
$\mathbf{X}^{2} / \mathbf{d f}$ & $2.164^{*}$ & $1.04^{*}$ & $0.811^{*}$ & $2.196^{*}$ & $2.165^{*}$ & $1.195^{*}$ & $1.800^{*}$ \\
RMSEA & $0.076^{*}$ & $0.014^{*}$ & $0.000^{*}$ & $0.078^{*}$ & $0.076^{*}$ & $0.078^{*}$ & $0.060^{*}$ \\
M-Model & Close Fit & Close Fit & Close Fit & Close Fit & Close Fit & Close Fit & Close Fit \\
\hline
\end{tabular}

Source: Data Processed

Note: SV = Social Values; PLS = Rate of Profit Loss Sharing; ST = State; RG = Regulation; GS = Goods and Service; CONS = Consumption; ISMD = Islamic Money Demand; $\chi^{2}=$ chi square, minimum fit function test $\left(\chi^{2} / \mathrm{df} \leq 3.0\right) ; \mathrm{RMSEA}=$ root mean square error of approximation $(\leq 0.08)$.

Table 3 demonstrates appropriate indices for a model of measurement designed to test Islamic money demand model. The LISREL modifying index was analyzed to decide if the hypothesized model needed addition or reduction of indicators. When evaluating measurement models, our reliability to a number of tests, as well as to other biases, did not rely on measured chi-square measures to determine general fit. The seven suggested measuring models best match the data among the alternative measuring models based on the selected fit indices.

RMSEA values (all below 0.08) suggest that the seven measuring models developed adequate measuring models. Overall, the results indicated that the seven measurement models for the constructs of the integrated Islamic social values and money demand function of muzakki fitted the data moderately.

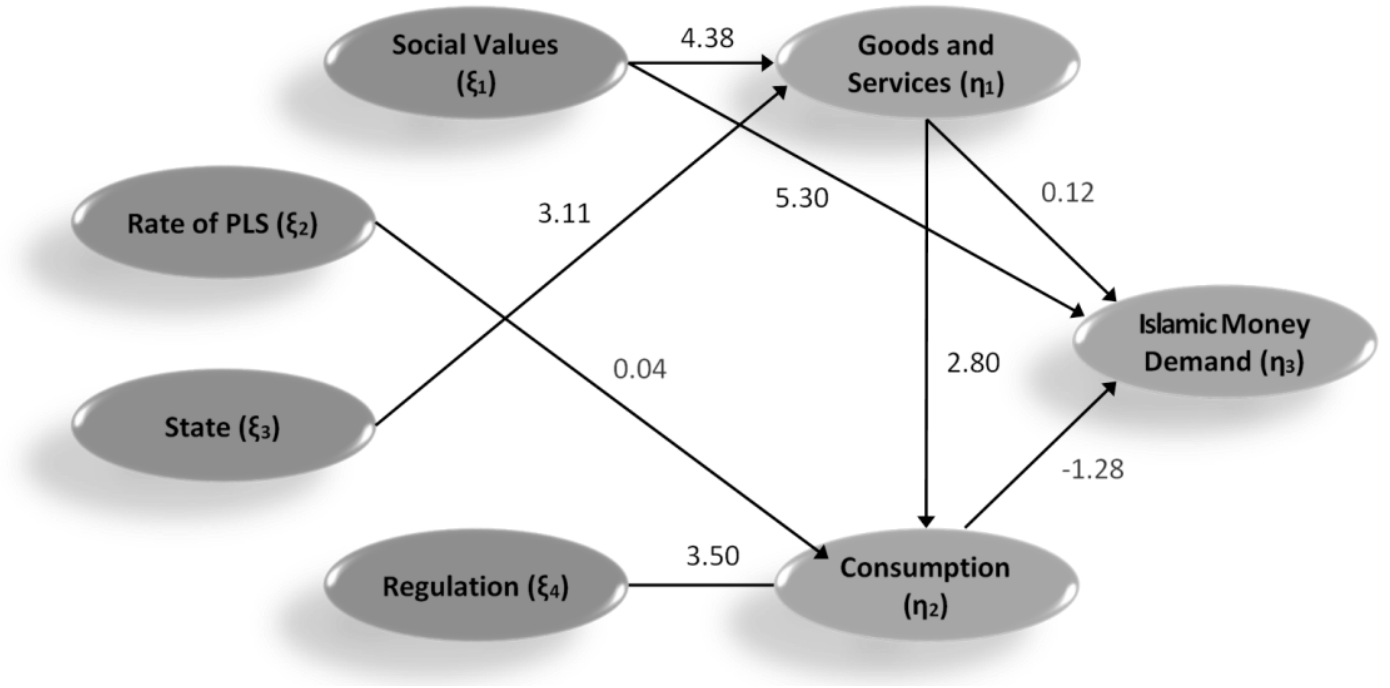

Source: Data Processed 
The following figure provides fitting indexes for the structural model to determine Islamic money demand. The results show that the proposed structural models better match the data from the statistical point of view between alternative structural models based on the selected fit indices $(\chi 2=2541.65 ; \mathrm{df}=1041 ; \rho=0.000)$ or $\mathrm{a}$ practical perspectives (RMSEA $=0.078$, and $\mathrm{RMR}=0.064 ; \mathrm{GFI}=0.663, \mathrm{AGFI}=0.619, \mathrm{NNFI}$ = 0.899; $\mathrm{CFI}=0.907$ ).

The RMSEA values (less than 0.08) suggested that the structural models were constructing suitable structural models. The goodness-of-fit index (GFI) has also risen to 0.80 , showing that more than 60 percent of item variances and covariances may be clarified by the proposed variables. All in all, the results showed that the model was reasonably suited by a structural model for the Islamic money demand.

The instrument of Islamic economic system may not only help minimize the instability in the aggregate of money demand but also influence the different components of the money demand in a different way that would promote greater efficiency and equity in the use of money. The results are different, based on research on the integration of social values and the demand for money in the micro-behaviour model. Some of them are in line with the first hypothesis, but the rest of them are not.

Islamic social values are significant affect the money demand $(5.30>1.96)$. The above result has shown that there is a relationship between social values and money demand. Social values also have a relationship or have been influenced by different components of demand for money. The above result has shown that there is a relationship between social values and goods and services $(4.38>1.96)$.

Table 4

Result for Islamic Money Demand Models

\begin{tabular}{lcc}
\hline \multicolumn{1}{c}{ Path } & t-Value & Conclusion \\
\hline Social Value $\rightarrow$ Good \& Service & 4.38 & Significant \\
Social Value $\rightarrow$ Is. Money Demand & 5.30 & Significant \\
PLS Rate $\rightarrow$ C. Consumption & 0.04 & Not Significant \\
State $\rightarrow$ Good \& Service & 3.11 & Significant \\
Regulation $\rightarrow$ C. Consumption & 3.50 & Significant \\
Good \& Service $\rightarrow$ C. Consumption & 2.80 & Significant \\
Good \& Service $\rightarrow$ Is. Money & 0.12 & Not Significant \\
Demand & & \\
Consumption $\rightarrow$ Is. Money Demand & -1.28 & Not Significant \\
\hline
\end{tabular}

Source: Data Processed

The result show the relations between Islamic social value and money demand. Islamic social values significantly influence each goods and services as well as money demand model. People will increase the motive for holding money if he wishes to donate some for social purposes. In general, if the people are prosperous, the money demand 
will increase. This study is appropriate with Chapra (1996) theory in monetary management in an Islamic economy, particularly Islamic money demand.

To minimizing instability in the aggregate demand for money, the various components of the Islamic economic system can influence the various parts of the money demand to promote increased effectiveness and equity in the use of money. The relatively higher stability of money demand in an Islamic economy can also lead to greater stability in the speed of money circulation. Kia and Darrat (2007) reviewed the stability of money demand in the interest-free economy, with emphasis on the role of agents. In line with these results, Ascarya et al. (2008) stated that money demand function for the Islamic economic system was derived from an economic environment free of interest.

Furthermore, given that demand for money linked to conspicuous consumption and speculation tends to be relatively unstable (Chapra, 1996; Gustiani et al., 2010), a high level of instability is injecting into the whole economy, rather than for necessity and productive investment. It is hardly surprising that recent empirical studies have shown great instability in the money demand function in its macro perspective.

Based on this study, the integrated money demand model in Islamic microeconomics perspective is influenced by social value variables. Zakat can influence the allocation of money that can help maximize Md, not for conspicuous consumption and speculation transaction. The level of expense on religious expenditure by Ezzati (2019); Hosseini (2010); Sobhani and Mehrbani (2008) is charity or expenditure in order to please God. They agreed that the most important factors affecting this variable are the level of income $Y$ and virtue (faith).

Modern muslim economics researchers (Ascarya et al., 2008; Gustiani et al., 2010; Setiadi, 2012; Widodo, 2015) applied the theory of money demand, which is based on the Keynesian approach in conventional economic. Further, according to the findings of this study, the element of money for a Muslim is followed by utility in Islamic economy by reducing transaction costs and the possibility of achieving nearness to God through the spiritual expenditure. Finally, they introduce three variables into the utility function: money, consumption expenditures, and charity (social values) in the form of an optimal control pattern. Taken as whole, the study shows that this integration model aimed to promote the demand for money through Islamic microeconomics perspective. Hence, this micro model needs to improve and integrate to promote the macroeconomics welfare.

\section{CONCLUSION}

The result shows the first overview of Islamic money demand based on the muzakki perspective. In certain models, the return of the Sharia is contrary to the 
consumption hypothesis, because conventional systems dominate the economic system. The impact of the social value variable on the demand for money evidence from Java's muzakki actually appeared for this study. Furthermore, the feasibility and practicability of the micro-approach Islamic money demand model in the real economy are determined by who holds the money; if muzakki, they have excess wealth to donate. However, if the respondent in this study is Mustahik, the results may vary.Due to the behavior that determines the demand for Islamic money in Indonesia, it can be suggested that we need more research into social values, particularly the respondent which is not only muzakki but also random sampling from Muslim adults. In order to prove that social value, especially the zakat instrument truly a monetary tool in the Islamic money demand system, we need more primary data on social value. In order to reevaluate its influence on monetary policy as an authority in the Islamic bank and economy system, the Bank of Indonesia should reconsider the social value variable.

This research add insights to the theory and practice of Islamic monetary policy. Bank Indonesia and BAZNAS, as the authority for the Islamic banking and economy system as well as the authority for philanthropic funds, are expected to re-consider social values variable to be more examined its influence in taking the monetary policy. For the next studies, the money demand should be observed by varying the indicators; re-decrease the social values variable for all social activities with more complex primary data, Islamic and conventional motives must be differentiated. We think the results of this analysis will be better.

\section{ACKNOWLEDGMENT}

The authors would like to thank the University of Darussalam Gontor for its supported, Fajrin for her research assistantship, as well as her team for the survey. Paper to be presented in the "the 4th International Conference of Zakat (ICONZ)", organized by Center of Strategic Studies, BAZNAS - Badan Zakat Amil Nasional, October 7 - 9, 2020. We hope that this research will aid in the development of the Islamic economy in Indonesia.

\section{REFERENCES}

Ascarya, A., Hasanah, H., \& Achsani, N. A. (2008). PERILAKU PERMINTAAN UANG DALAM SISTEM MONETER GANDA DI INDONESIA. Buletin Ekonomi Moneter Dan Perbankan, 11(1 SE-Articles). https://doi.org/10.21098/bemp.v11i1.235

Ascarya and Masrifah, A. R. (2016). Aplikasi Structural Equation Model ( SEM ). In Manual Metodologi.

Bagozzi, R. P., \& Yi, Y. (2012). Specification, evaluation, and interpretation of structural equation models. Journal of the Academy of Marketing Science, 40(1), 8-34. 
https://doi.org/10.1007/s11747-011-0278-x

Calza, A., \& Zaghini, A. (2010). Sectoral Money Demand and the Great Disinflation in the United States. Journal of Money, Credit and Banking, 42(8), 1663-1678. https://doi.org/10.1111/j.1538-4616.2010.00358.x

Chapra, Muhammad Umer. (1979). The Islamic welfare state and its role in the economy. Islamic Foundation.

Chapra, Muhammad Umer. (2011). The Global Financial Crisis: Can Islamic Finance Help? In Islamic Economics and Finance (pp. 135-142). IE Business Publishing. https://doi.org/10.1057/9780230361133_5

Chapra, Muhammar Umer. (1996). Monetar Management in An Islamic Economy. Islamic Economic Studies, 4(1).

https://papers.ssrn.com/sol3/papers.cfm?abstract_id=3165360

Chapra, U. (2001). The Future of Economics(an Islamic Perspective). SEBI.

Civelek, M. E. (2018). Essentials of Structural Equation Modeling Essentials of Structural Equation Modeling. University of Nebraska.

Cleveland, M. J., Gibbons, F. X., Gerrard, M., Pomery, E. A., \& Brody, G. H. (2005). The impact of parenting on risk cognitions and risk behavior: A study of mediation and moderation in a panel of African American adolescents. In Child Development (Vol. 76, Issue 4, pp. 900-916). https://doi.org/10.1111/j.1467-8624.2005.00885.x

Dreger, C., \& Wolters, J. (2010). Investigating M3 money demand in the euro area. Journal of International Money and Finance, 29(1), 111-122. https://doi.org/10.1016/j.jimonfin.2009.02.002

Esmaeili, F., Sadr, S. K., \& Noferesti, M. (2012). Money demand in an interest free economy. Journal of Economic Research, 47(98), 129-151. https://ikr.inceif.org/handle/INCEIF/1767

Ezzati, M. (2019). Contributing factors on the allocation of funds in the Islamic society: The case of financing tools for Islamic banks. Journal of Islamic Marketing, 10(4), 1074-1090. https://doi.org/10.1108/JIMA-02-2017-0017

Gustiani, E. D., Ascarya, A., \& Effendi, J. (2010). ANALISIS PENGARUH SOCIAL VALUES TERHADAP JUMLAH PERMINTAAN UANG ISLAM DI INDONESIA. Buletin Ekonomi Moneter Dan Perbankan, 12(4 SE-Articles). https://doi.org/10.21098/bemp.v12i4.246

Hair, J. F., Black, W. C., Babin, B. J., Anderson, R. E., \& Tatham, R. (2006). Multivariate data analysis. Uppersaddle River. NJ: Pearson Prentice Hall.

Hoe, S. L. (2008). Issues and Procedures in Adopting Structural Equation Modelling Technique. Journal of Quantitative Methods, 3(1). https://ink.library.smu.edu.sg/sis_research/5168

Hosseini, S. R. (2010). THE DESIRABLE CONSUMPTION PATTERN IN THE FRAMEWORK OF THE ISLAMIC MODEL OF ALLOCATION OF INCOME. EGHTESAD-E ISLAMI, 8(34), 738. https://www.sid.ir/en/journal/ViewPaper.aspx?id=178100

Jöreskog, K. G., \& Sörbom, D. (1982). Recent Developments in Structural Equation Modeling. Journal of Marketing Research, 19(4), 404-416. https://doi.org/10.1177/002224378201900402

Keesling, J. W. (1973). MAXIMUM LIKELIHOOD APPROACHES TO CAUSAL FLOW 
ANALYSIS. The University of Chicago.

Kia, A., \& Darrat, A. F. (2007). Modeling money demand under the profit-sharing banking scheme: Some evidence on policy invariance and long-run stability. Global Finance Journal, 18(1), 104-123. https://doi.org/10.1016/j.gfj.2006.11.001

Mazher, M. A., \& Dahlan, J. (2020). Determining Factor for Malaysian Money Demand Function. International Journal of Economics, Business and Accounting Research (IJEBAR), 4(03), 79-90. https://doi.org/10.29040/ijebar.v4i03.1091

Padhan, P. C. (2011). Stability of Demand for Money in India: Evidence from Monetary and Liquidity Aggregates. International Journal of Economics and Finance, 3(1), 271282. https://doi.org/10.5539/ijef.v3n1p271

Riyandi, G. (2012). META-ANALYSIS OF MONEY DEMAND IN INDONESIA. Buletin Ekonomi Moneter Dan Perbankan, 15(1 SE-Articles). https://doi.org/10.21098/bemp.v15i1.415

Sadeghi, F., \& Rofougar, S. K. (2019). THE MONEY DEMAND FUNCTIONS IN ISLAMIC ECONOMY: NEW EVIDENCE FROM IRAN-ARDL APPROACH. Journal of Islamic Monetary Economics and Finance, 4(2 SE-Articles). https://doi.org/10.21098/jimf.v4i2.922

Setiadi, I. O. (2012). Analisis Faktor-Faktor yang Mempengaruhi Permintaan Uang di Indonesia Tahun 1999:Q1 - 2010:Q4 dengan Pendekatan Error Correction Model (ECM) [Universitas Negeri Semarang]. http://lib.unnes.ac.id/id/eprint/18021

Sobhani, H., \& Mehrbani, V. (2008). THE EXPLORATION OF THE EFFECT OF PHILANTHROPIC CONTRIBUTIONS ON INCOME INEQUALITY IN IRAN.

Sude, M. F. J. R., \& Umam, K. (2018). An Empirical Study on The INfluence of Islamic Values on Money Demand (Case Study: University of Darussalam, Gontor and Mantingan Campus). Islamic Economics Journal, 4(2). https://doi.org/10.21111/iej.v4i2.2967

Suliman, S. Z., \& Dafaalla, H. A. (2011). An econometric analysis of money demand function in Sudan, 1960 to 2010. 3(16), 793-800. https://doi.org/10.5897/JEIF11.122

Widodo, A. (2015). Faktor-Faktor Makroekonomi yang Mempengaruhi Permintaan Uang di Indonesia. Jurnal Ekonomi Dan Studi Pembangunan, 16(1), 63-72. https://journal.umy.ac.id/index.php/esp/article/view/1222

Wijanto, S. H. (2015). Metode Penelitian Menggunakan Structural Equation Modelling dengan LISREL 9 (1st ed.). Lembaga Penerbit Fakultas Ekonomi Universitas Indonesia.

Wiley, D. E. (1973). The identification problem for structural equation models with unmeasured variables. Structural Equation Models in the Social Sciences, 69-83.

Winarsih, R., Masrifah, A., \& Umam, K. (2019). THE INTEGRATION OF ISLAMIC COMMERCIAL AND SOCIAL ECONOMY THROUGH PRODUCTIVE WAQF TO PROMOTE PESANTREN WELFARE. Journal of Islamic Monetary Economics and Finance, 5 (2 SEArticles). https://doi.org/10.21098/jimf.v5i2.1065 